\title{
Magyarország Nemzeti Atlasza új kiadásának digitális margójára
}

\author{
Klinghammer István
}

DOI: https://doi.org/10.30921/GK.71.2019.2.1

Absztrakt: A statisztikai adatok térképi ábrázolásának kezdete a 19. század közepe. A földrajzosok felfedezték a grafikus módszerek jelentôségét az információközlés és szemléltetés területén, és éltek a lehetôséggel. A statisztikai térképek természetföldrajzi atlaszokba történö felvételével alakult ki német nyelvterületen a „physikalisch-statistischer Atlas” típusa. A század utolsó harmadában a grafikus módszerek oktatása szerepet kapott a felsố iskolákban. A 20. század elején jelentek meg a grafikai munkákban a diagramok és részben a kartogramok is. A 20. század második felének módszertani munkái készitették elö a digitális térképészet kartográfiai kommunikációjának számítógépes megjelenését.

Abstract: Statistical data were first presented in maps only in the mid-19th century. Geographers discovered the force and importance of geographic methods in the transfer of information and illustration, and they widely used this opportunity. In the German language area, the "physikalisch-statistischer Atlas"-type developed, which included statistical maps in physical geographical atlases. In the last third of the century, the teaching of graphic methods was introduced in higher education. Diagrams and partly cartograms appeared in graphic publications in the early twentieth century. The methodological studies made in the second half of the 20th century prepared the birth of cartographic communication of digital cartography by computers.

Kulcsszavak: statisztikai atlaszok, tematikus térképek, kartográfiai kommunikáció Keywords: statistical atlases, thematic maps, cartographic communication

\section{A statisztikai adatok térképi ábrázolásának kezdete}

A 19. század közepére kialakult adatmegjelenítési módszerek kartográfiai alkalmazása a század végén általános és gyors fejlôdésnek indult. A statisztikusok, mérnökök és közgazdászok által kidolgozott grafikus ábrázolások a nemzetközi kommunikáció új formáiként szemléltették a már metrikus rendszerbe illesztett adatokat. A rajzi ábrázolás (közérthetôsége miatt) a statisztikai képzettséggel nem rendelkezók eszköztárába is bevonult. A földrajzosok felfedezték a módszerek jelentôségét az információközlés és a szemléltetés területén, és mind gyakrabban éltek a lehetôséggel, hogy eredményeiket grafikusan is közzétegyék.

Az 1857-es bécsi III. Nemzetközi Statisztikai Kongresszus és a következô kongresszusok térképkiállításai, amelyek közül az 1876-os budapesti volt a legátfogóbb, valamint az 1851tôl megrendezett világkiállítások kartográfiai bemutatói is nagy nemzetközi nyilvánosságot biztosítottak az új módszereknek.

Az 1851-es, Londonban rendezett elsô világkiállításon például a nagyközönség számára napi idôjárástérképeket nyomtattak. Az azonos idôpontra vonatkozó adatokat távírón keresztül szerezték meg, majd a térképeket a Hyde Parkban felállított litográfiai múhelyben sokszorosították. Az 1878-as párizsi világkiállítás anyaga bizonyította legmeggyőzőbben, hogy a grafikus módszereket hatékonyan lehet felhasználni a legkülönbözóbb adattípusok megjelenítésére. A kortárs tudósító annak idején hangsúlyozottan kiemelte az ábrázolási módok sokféleségét (Hall 1879).

Ugyanebben az idôben, az 1870-es évek végén jelent meg a francia Marey klasszikus múve, amely összefoglalta a különféle grafikus eljárásokat (Marey 1878). Különösen a könyv elsố része foglalkozott a statisztikai adatok rajzi megjelenítésének módszereivel. A grafikus módszerek kiváló alkalmazhatósága kiváltotta lelkesedés átterjedt a múszaki tudományok területére is, ahol a grafikus kalkuláció fejlôdése során kialakult a nomográfia speciális területe, amely a számítógépes adatfeldolgozás elốtt a kartográfiában is jelentôs szerepet töltött be (Kelnhoffer 1974).

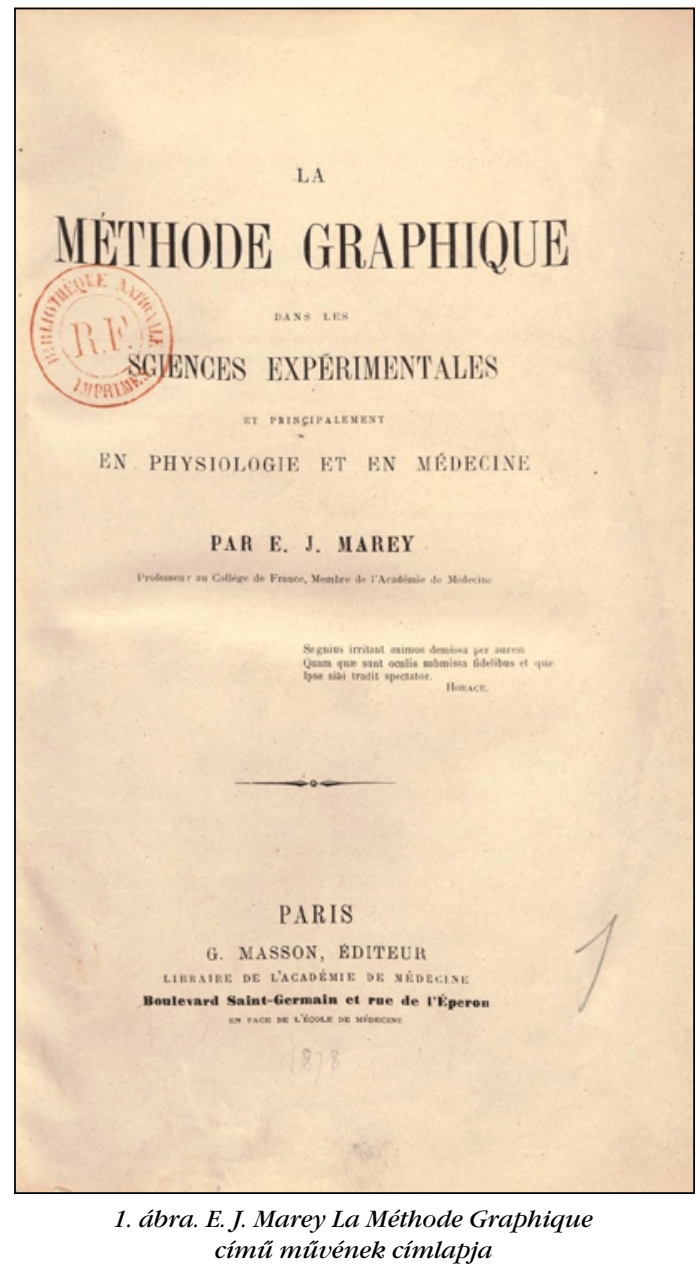




\section{A természetföldrajzi - statisztikai atlaszok megjelenése}

Heinrich Berghaus (1797-1884) német geográfus 1838 és 1848 között kiadott atlasza, a „Physikalischer Atlas”, megteremtette az elsố tematikus világatlaszt. Ebben a múben a korabeli természeti és emberföldrajzi, illetve a rokon tudományokkal kapcsolatos, például növénytani, néprajzi, állatföldrajzi tematikájú térképeket gyújtötte össze. A térképekkel meglehetősen pontosan sikerült a különféle statisztikai adatokat megjeleníteni, ezért joggal nevezték a hasonló ábrázolásokat statisztikai térképeknek, gyújteményeiket pedig statisztikai atlaszoknak.

A statisztikai térképek természetföldrajzi atlaszokba történô felvételével alakult ki német nyelvterületen a "physikalisch-statistischer Atlas" típusa, a természetföldrajzi-statisztikai atlasz. Ez a 19. század második felében a nemzeti atlaszok egy korai formáját képviselte, amelyben az általános és a tematikus rész szorosan kapcsolódott egymáshoz. A természetföldrajzi rész a domborzatot, a hőmérsékleti és csapadékviszonyokat fóként izovonalakkal ábrázolta, amit a geológiai, bányászati, talajtani, erdészeti és növényzeti térképek egészítettek ki. A statisztikai részben felületkartogramokkal szemléltették az adatokat, és a kartográfiai ábrázolást szöveges leírással egészítették ki.

Ezt az atlasztípust reprezentálja a két német földrajzos, Richard Andree (1835-1912) és Oskar Peschel (18261875) Lipcsében 1878-ban kiadott „Physikalischer-statististischer Atlas des Deutsches Reiches", és az osztrák földrajzos-meteorológus Joseph Chavanne (1846-1902) 1882 és 1887 között Bécsben megjelent „Physikalischer-Statistischer Atlas von Österreich-Ungarn" címú múve. Az említett komplex atlaszok mellett a 19. század második felében számos szakatlasz: klíma-, nyelv-, mezôgazdasági és ipari atlasz is megjelent Európában.

Az 1857-es bécsi Nemzetközi Statisztikai Kongresszus után, az ott elfogadott ábrázolási megegyezéseknek megfelelóen jelentek meg az elsô „hivatalos” kiadványok, amelyek közül kiemelkedett az osztrák statisztikus, Adolf Ficker (1816-1880) 1860-ban Gothában kiadott munkája, a „Bevölkerung der Österreichischen Monarchie". Múvében tizenkét lépcsôs(!) rasztersorozat alkalmazásával szerkesztette a felületkartogramokat. Múvét 1871-ben Berlinben August Meitzen statisztikus (1822-1910) mezógazdasági atlasza, a „Der Boden, die landwirtschaftlichen Verhältnisse des Preussischen Staates nach dem Gebietsumfange von 1866" követte. Kitûnô példákat tartalmaz a Párizsban 1874-ben megjelent „La démographie figurée de la France...”, az antropológus-statisztikus Louis-Adolphe Bertillon (1821-1883) munkája. A korszak legkiválóbb hivatalos statisztikai kiadványa azonban az Èmile Cheysson mérnök vezette „Bureau de la Statistique graphique" által 1879 és 1897 között évente megjelentetett egy-egy átfogó kötet, az „Album de Statistique graphique” volt. A kitûnô felépítés és az alkalmazott ábrázolási módszerek sokfélesége a sorozatot a statisztikai adatok rajzi megjelenítésének követendố példájává tették.

Az USA-ban a 19. század második felétôl élénkült meg a grafikus statisztika iránti érdeklôdés. Amerikai munkákat elôször az 1863-as berlini Nemzetközi Kongresszuson mutattak

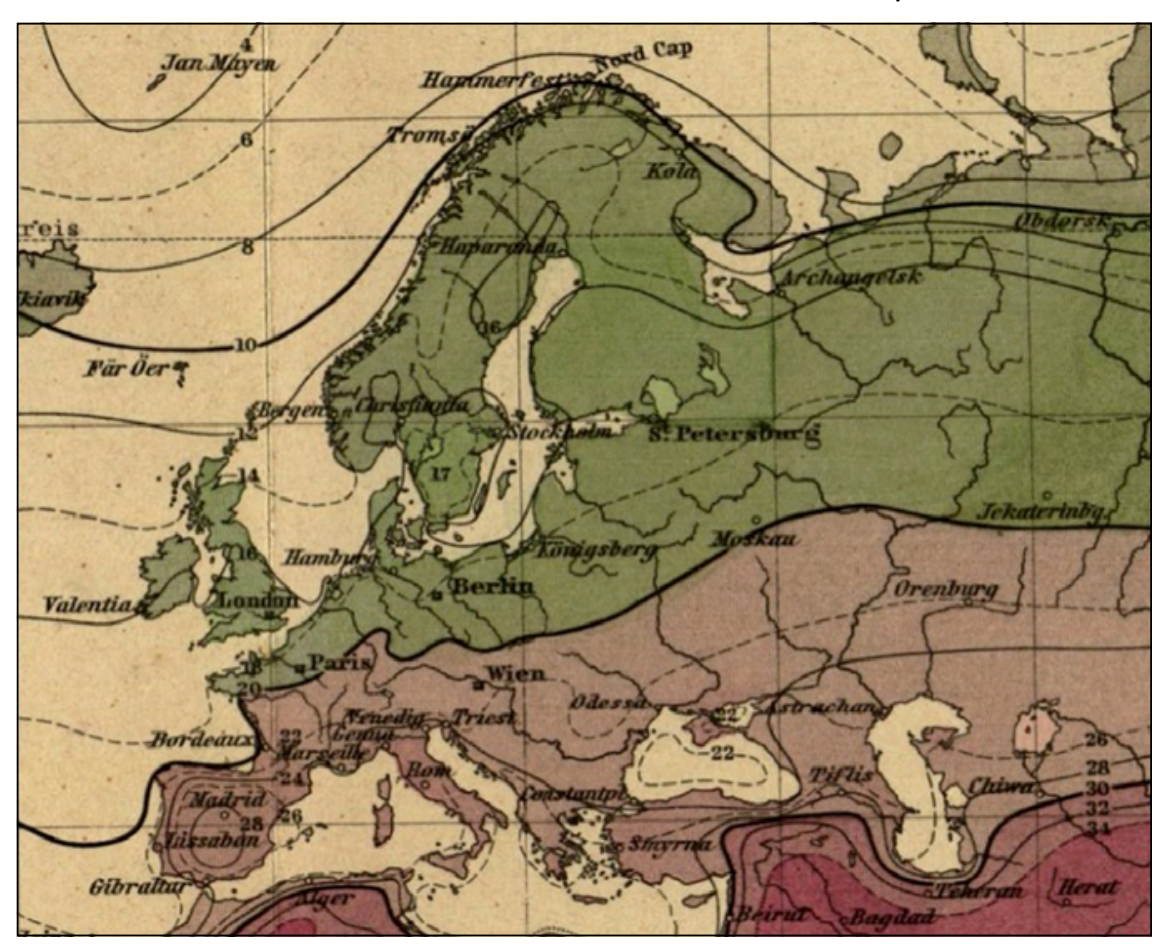

2. ábra. Izotermatérkép Heinrich Berghaus Physikalischer Atlasából

be. A diagramok és kartogramok széleskörú alkalmazása az Amerikai Egyesült Államokban az 1872-es kilencedik népszámlálás után kezdôdött, korábban jószerint csak a demográfiai alapadatokat szemléltették. 1874ben jelent meg a Francis A. Walker (1840-1897) statisztikus irányításával készült hatvan lapos térképgyújtemény, a „Statistical Atlas of the Results of the Ninth Census...", amely az amerikai népszámlálás adatait hat- és többszínú, új formájú jelkartogramokkal ábrázolta. ${ }^{1}$ A statisztikai adatok ábrázolásának elsố tetôpontját az 1898-as tizedik és az 1903-as tizenegyedik népszámlálás atlaszai jelentették. A Henry Gannett (1846-1914) fôgeográfus irányításával készült munkákban nyomtatott színekkel az összes diagram- és kartogramforma fellelhetô.

Nagy-Britanniában a grafikus módszereket inkább kutatási, mint tájékoztatási célú ábrázolásokra használták, hiányoztak a német, francia vagy amerikai statisztikai atlaszokhoz hasonló kiadványok. Jól példázza ezt az, hogy a francia É. Levassuer (1828-1911) a Londoni Statistical Society 1885-ös jubileumi rendezvényén a grafikus adatok megjelenítését mint új területet mutatta be az angol közönségnek.

1 A térképeket Julius Bien Litográfiai Intézetében, New Yorkban nyomtatták. 


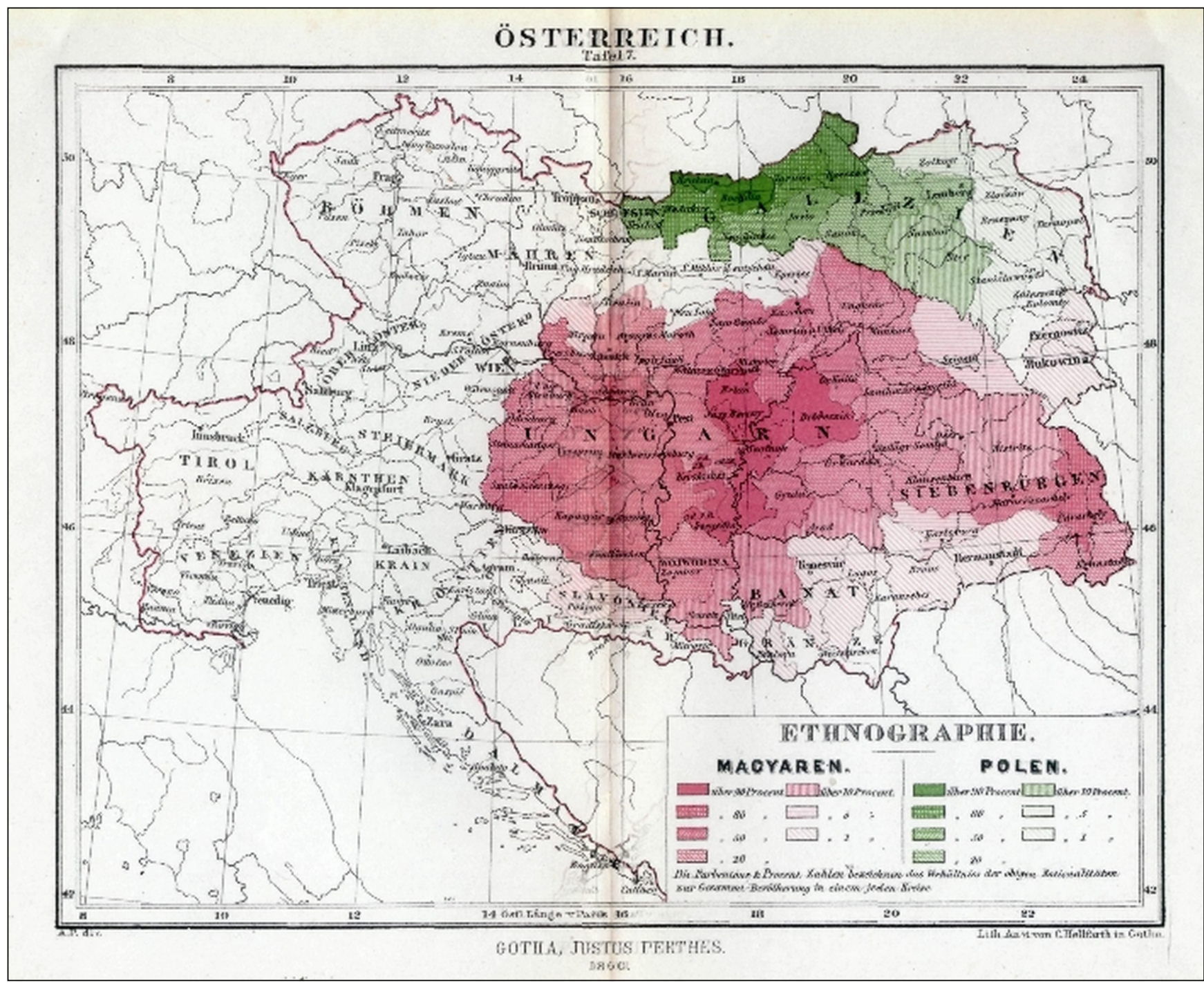

3. ábra. Részlet Adolf Ficker Bevölkerung der Österreichischen Monarchie címú atlaszából

\section{A grafikus módszerek megjelenése az oktatásban}

Már az 1869-es hágai Nemzetközi Statisztikai Kongresszuson javasolták a statisztikai eljárások bevezetését a magasabb iskolákba, mégis Levassuer 1876-os budapesti kongresszusra készített „Memoire”-jáig vajmi kevés történt ezen a területen. Levassuer kitúnô pedagógiai érzékét mutatja, hogy saját földrajzi tankönyveiben és munkáiban már 1868tól szerepeltetett ábrákat is. Ennek hatására a diagramokat és kartogramokat Franciaországban bevették a tananyagba. A budapesti kongresszus határozata ajánlotta elôször a grafikus és kartográfiai módszerek oktatásának bevezetését a menynyiségi értékek szemléltetésére. Különös módon azonban Levassuer és az ugyancsak francia Jean Jacques
Reclus (1830-1905) múveit kivéve, a 20. század elejéig a földrajzi szövegekbôl hiányoztak a rajzi és kartográfiai ábrázolások. A század elején jelentek meg a geográfiai munkákban a diagramok, mindenekelốtt az egyszerú pálcikadiagramok és részben a kartogramok is.

A növekvố számú tematikus ábrázolás az oktatás és a nevelés kérdéseivel összefüggésben, ráirányította a figyelmet a grafikus ábrázolások „felfogásának" pszichológiai hátterére. Miután angol nyelven összefoglaló könyvek jelentek meg, mind az Egyesült Államokban, mind Angliában, a menynyiségi információk rajzi megjelenítésének szerkesztési módszereirôl, (Palmer 1921) hamarosan megjelentek az elsố térképhasználatot, a formák felismerhetôségét vizsgáló tanulmányok. Az ismertté vált korai munkák közé tartozik Eells 1926-ban publikált munkája a pálcika- és kördiagramok olvashatóságának és becsülhetôségének pontosságáról (Eels 1926). A vizsgálat szerint az olvashatóság szinte azonos a két diagramformánál, a körök viszont könynyebben becsülhetônek bizonyultak. Croxton a húszas évek végén kezdte kísérleteit, amelyekben osztott pálcika- és kördiagramokat hasonlított össze. Elôzetes jelentése szerint a pálcikadiagramok olvashatóbbak voltak a mennyiségi adatok összehasonlításában (Croxton 1927). Néhány hónappal késôbb azonban a végleges jelentésben már a kördiagramok alkalmazásának elónyeit(!) fogalmazta meg (CroxtonStryker 1927). Az ugyanebben az időben megjelent Washburne-tanulmány a tesztmellékletek rossz minôsége miatt csekély hatást váltott ki (Waschburne 1927). Néhány évvel késôbb érdekes összehasonlító tanulmányt tett közé Croxton és Stein a pálcikadiagramok, 
négyzetek, körök és kockák felfoghatóságáról. A teszt szerint a legjobban olvashatók a pálcikák voltak, a körök és négyzetek esetében nem találtak különbséget, míg a legrosszabb eredményeket a kockák felismerésénél tapasztalták (Croxton-Stein 1932). Thomas az iskolás gyermekek körében folytatott vizsgálatokkal az életkori sajátosságokra helyezte a hangsúlyt (Thomas 1933).

Az 1930-as években német nyelvterületen is folytak hasonló kutatások. Peters a felületarányos mennyiségbecslésnél a forma hatásának tanulmányozásával foglalkozott (Peters 1933). Kasting ugyanekkor a mennyiségek felismerésének és összehasonlításának pszichológiáját vizsgálta (Kasting 1935).

\section{Módszertani fejlódés a digitális térképészet megjelenéséig}

A statisztikai eredményeknek a 20. század elsố felében még mindig viszonylag csekély körû elterjedtsége és népszerúsége vezetett egy új grafikus ábrázolási forma, a képstatisztika (picture statistics) kifejlesztéséhez. Ennek kezdetei még az 1880-as évekre nyúlnak vissza.

George Mulhall (1836-1900) angol statisztikus számít a képstatisztika és a piktogramok úttörôjének. Mulhall 1884-ben Londonban megjelent könyve, a „Dictionary of Statistics” tartalmazott elôször mennyiségeket kifejezô és érték összehasonlításra alkalmas, különbözố nagyságú stilizált képeket. ${ }^{2}$ Érdekes azonban, hogy Mulhall késôbbi múvében, az 1896ban kiadott „Industries and Wealth of Nations"-ben mégis visszatért az akkora már hagyományosnak számító grafikonokhoz és diagramokhoz.

A francia Jacques Bertillon más területen kereste a grafikus ábrázolások gyors felismerhetôségének és közérthetőségének kulcsát: a szín és forma társításával próbálta hatékonyabbá tenni a közlést. Bertillon felismerte, hogy az általa javasolt módszer elónyei elsôsorban a kiállításokon és az oktatásban való kitûnố alkalmazásban

\footnotetext{
2 A mú a századfordulóig még három kiadásban jelent meg $(1886,1892,1899)$.
}

rejlenek, míg tudományos célokra ez a rendszer kevésbé alkalmas (Bertillon 1895).

A századforduló környékén vitathatatlanul nagy népszerûségnek örvendô képszerú ábrázolásokat azonban több vezetô statisztikus is bírálta. Az összehasonlítás nehézségét emelték ki. Az amerikai Brinton ennek leküzdésére a különbözô nagyságú, és ezért csak nehezen összehasonlítható képszerú jelek helyett az azonos nagyságú, azonos értéket képviseló, és így megszámlálható jelek alkalmazását javasolta (Brinton 1914). A hasonló elveken kidolgozott, nemzetközileg is elismertté vált módszer, a „Wiener Methode der Bildstatistik" megalkotása, Otto Neurath (1882-1945) osztrák szociológus és közgazdász nevéhez füzôdik (Neurath 1933). Neurath elsôdleges célja az volt, hogy a nagyközönség számára érthetố módon mutassa be a nagyságokat és a közöttük fennálló viszonyt. Ennek lehetôségeit vizsgálva vezette be a mennyiségkép, a „Mengenbild” fogalmát. Neurath elvébôl, hogy a nagyobb mennyiségek kifejezésére ismételni kell az értékegységeket, fejlôdött ki a tematikus kartográfia értékegységmódszere. Neurath egységesítette az amerikai Brinton, Haskell (Haskell 1920) és Karsten (Karsten 1923) által használt jeleket és a képszerú jeleket, ezzel jelentôsen hozzájárulva a képstatisztika fejlődéséhez. A két világháború között New Yorkban külön iroda múködött, amely a képstatisztikának a közérdekú információk közlésében való felhasználásával foglalkozott.

A 20. század második felében a tematikus kartográfia módszertani kérdéseinek vizsgálatában az angol nyelvterület járt elól. Angliában gyors egymás utánban több tankönyv is megjelent, amelyek a „megjelenítéssel” foglalkoztak, és már a címükben jelezték a kartográfiához való szoros kötôdésüket. Az elsôk közé tartozott Birch „Maps topographical and statistical" címú kötete, melynek elsô, 1949-es oxfordi kiadását tizenöt évvel késôbb, 1964 ben követte a második. Röviddel Birch könyve után, 1952-ben látott napvilágot Londonban Monkhouse és Wilkinson alapmúve, a „Maps and Diagrams”, amely egyetemi tankönyvként a hatvanas évekig számos utánnyomást ért meg, és melynek második kiadása 1963 óta ma is szerepel a kézikönyvek között. Dickinson „Statistical Mapping and the Presentation of Statistics" címú tankönyve a mennyiségi adatok megjelenítésének kérdéséről 1963-ban, Londonban jelent meg.

Az angol nyelvterület tehát felkészült volt, amikor az amerikai Waldo Tobler (1930-2018) 1959-ben az elsôk között már a kartográfia automatizálásáról beszélt (Tobler 1959).

Nyugat-és Közép-Európában ebben az idôben jelentôs volt a lemaradás. A két világháború közötti idôszaktól kezdôdốn a statisztikai kutatások eredményeit már nem statisztikusok és közgazdászok, hanem általában kevés matematikai és statisztikai ismerettel rendelkező geográfusok jelenítették meg. Csak a század közepén kezdtek a kartográfusok is ezzel foglalkozni, akiknek addig nem volt dolguk tömeges statisztikai adatokkal. A megváltozott feldolgozói kör következtében a matematikai statisztikai módszereket csak csekély mértékben alkalmazták, és ugyanígy háttérbe szorult néhány ábrázolási forma, mint például a diagramok. Korábban ugyan már definiálták a jel- és felületkartogram közötti különbséget, most azonban ezt ismételten meghatározták. Hasonló okokra vezethetố vissza a nyelvi következetlenség az izovonalas ábrázolások megnevezésénél. A grafikus adatábrázolás új kapcsolódása a földrajzhoz inkább hátráltatta, mintsem gyorsította a szükséges lépések megtételét az elektronikus adatfeldolgozásra való forradalmi átmenet küszöbén. A német nyelvterületen a „statisztikai térkép” kifejezést, amely a hatvanas években még megjelent a szakirodalomban, elutasították. ${ }^{3}$ Ezzel szemben angol nyelvterületen

\footnotetext{
3 Az 1960-as évek közepéig német nyelvterületen kevés módszertani újdonság született. Jensch 1951-ben, Fischer pedig 1954-ben nemlineáris jelméretarány kialakításával kísérletezett. Foglalkoztak a kartográfiai kifejezés alapformáival, például Louis 1957-es munkájában, és a jelek kérdéseivel, ahogyan Arnberger 1963-as, valamint Frenzel és Ogrissek 1965-ös tanulmányai bizonyítják Majd Imhof 1962-ben és Pillewizer 1964 ben összefoglalta a kartográfia alapszerkeze tét. A hatvanas években, mintegy a módszertani fejlôdés betetôzéseként, jelentek meg a tematikus kartográfia monográfiái, 1966ban Arnberger, 1967-ben Witt munkája.
} 
ezt a megnevezést, amely világosan mutatta a statisztika tudományához való kötôdést, és annak illetékességét az adatmegjelenítésben, továbbra is használták. A nagy adattömegek feldolgozásának meglévô technológiái tehát a grafikus eljárások számára is rendelkezésre álltak.

Az 1960-as évek elejétôl kezdi meg a rendszeres szakmai találkozók szervezését az 1959-ben alapított "International Cartographic Association”. A tradicionális térképészet korszakát a grafikus ábrázolás törvényszerúségeit megfogalmazó grafikus szemiológia foglalta össze. A francia Jacques Bertin (1918-2010) nevéhez fưzôdô irányzatot nem kis mértékben a tematikus kartográfia ábrázolási nehézségeinek megoldására dolgozták ki Franciaországban (Bertin 1967). A tematikus kartográfia kérdéseinek elôtérbe kerülését jelzi Bertin azon kijelentése, hogy „a topográfiai térképészet nem támaszt semmilyen problémát a jelekkel és szimbólumokkal kapcsolatban" (Bertin 1978). A tematikus térképen azonban az adatok közötti viszonyokban rejlô, általában mennyiségi információt kell megjeleníteni, amihez Bertin szerint a látóképességból levezetett hat vizuális változót használhatjuk fel, amelyek egyetemesen alkalmazhatók a grafikus közlés elméletének kidolgozásánál.

Míg Nyugat- és Közép-Európában a hagyományos térképgrafika ábrázolási formái képezték a vizsgálatok központi témáit, addig az angolszász országokban már egy újabb elméleti irányzat kezdett formálódni. A kartográfiai információ és kartográfiai kommunikáció fogalmak a hatvanas évek végétôl egyre gyakrabban tû́nnek fel a térképészeti szakirodalomban. A szakmai közvélemény számára az áttörést a Nemzetközi Térképészeti Társulás Delhiben rendezett konferenciáján elhangzott előadás jelentette 1968-ban. Ebben a cseh Kolačny rendkívül tömören és szemléletesen fejtette ki: a kartográfia kommunikációs tudományág. A gondolat hamarosan meghatározó jelentôségúvé vált. A kartográfiai kommunikáció elméleti keretében megkezdődött a hagyományos nyomtatott térképekre épülő

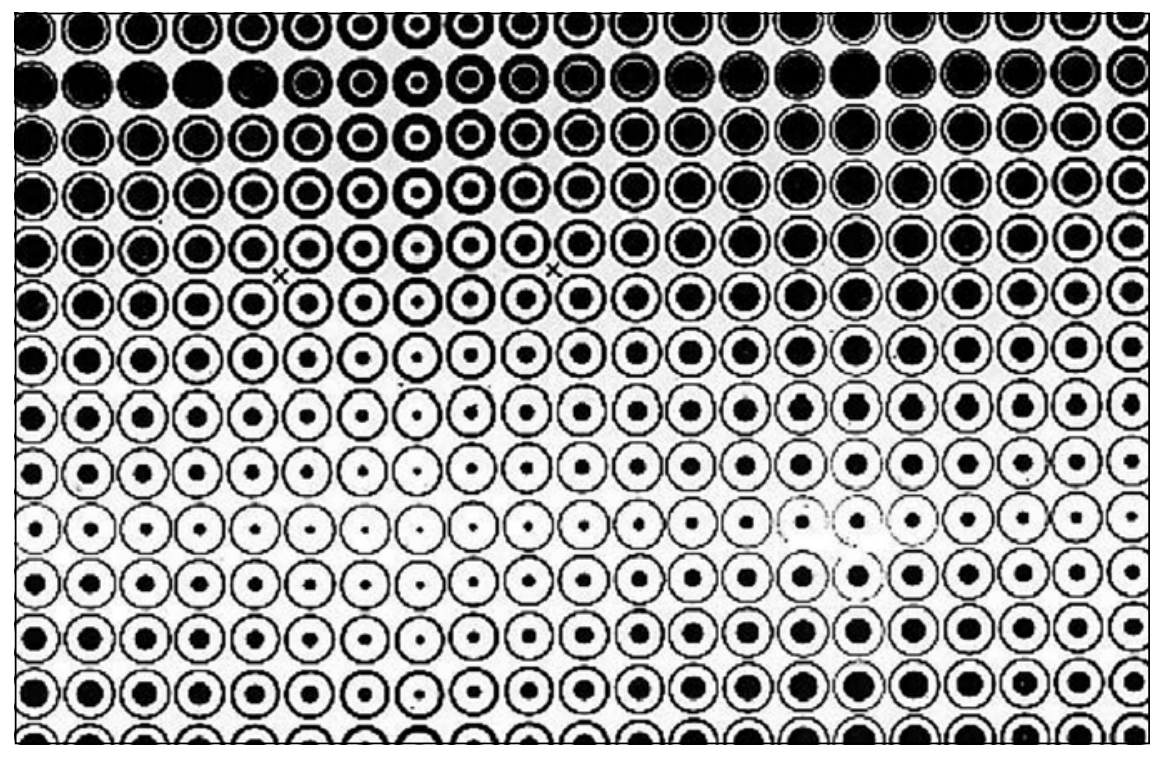

4. ábra. Részlet Jacques Bertin Sémiologie Graphique címü könyvének boritójából

tudományág forradalmi átalakulása az új, digitális kartográfia korszakába (Klinghammer 1991, 2010).

\section{Irodalomjegyzék}

Bertillon, J. 1895. Des representation graphiques. In: Course élémentaire de statistique administrative. Paris.

Bertin, J. 1967. Sémiologie Graphique. Paris.

Bertin, J. 1979. Visual perception and cartographic transcription. In World Cartography 15. p. 18

Brinton, W. C. 1914. Graphic Methods for Presenting Facts. New York.

Croxton, F. E. - Stein, H. 1932. Graphic Comparison by Bars, Squares, Circles and Cubes. In Journal of the American Statistical Association 27, pp. 54-60. DOI: https://doi. org/10.1080/01621459.1932.10503227

Croxton, F. E. - Stryker, R. E. 1927. Bar Charts Versus Circle Diagrams. In Journal of the American Statistical Asocciation 22, pp 473-482. DOI: https://doi.org/10.1080/01 621459.1927 .10502976

Croxton, F. E. 1927. II Some Additional Data, In Journal of the American Statistical Association 22, pp. 36-39. DOI: https://doi. org/10.1080/01621459.1927.10502939

Eells, W. C. 1926. The Relative Merits of Circles and Bars for Representing Component Parts. In Journal of the American Statistical Association 21, pp. 119-132. DOI: https://doi. org/10.1080/01621459.1926.10502165

Hall, S. 1879. The Graphic Method. In The Nation 29, pp. 238-239.

Haskell, A. C. 1920. Graphic Charts in Business How to Make and Use them. New York.

Karsten, K. G. 1923. Charts and Graphs. An Introduction to Graphic Methods int he Control and Analysis of Statistics. New York.

Kasting, K. 1935. Über Mengenauffassung und Mengenvergleich. In Archiv für gesamte Psychologie 94, pp. 247-270.

Kelnhoffer, F. 1974. Nomogramme in der thematischen Kartographie. In Mitteilungen der Österreichischen Geographischen Gesellschaft 116, pp. 351-389.
Klinghammer, I. (szerk.) 2010.Térképészet és geoinformatika. ELTE Eötvös Kiadó, Budapest. p. 364

Klinghammer, I. 1991. A kartográfia kialakulása napjainkig. Tudománytörténeti áttekintés a kezdetektôl a digitális tematikus térképek szerkesztéséig. MTA doktori értekezés. Budapest.

Marey, E. J. 1878. La mèthode graphique dans les sciences expérimentales et principalement en physiologie et mèdecine. Paris.

Neurath, O. 1933. Bildstatistik nach Wiener Methode in der Schule. Wien-Leipzig.

Palmer, A. R. 1921. The Use of Graphs in Commerce \& Industrie. London.

Peters, W. 1933. Versuche über den Einfluss der Form auf die Wahrnehmung von Flächengrössen. In Zeitschrift für Psychologie 129, pp. 323-337.

Rose, T. G. 1930. Bussiness Charts. A Clear Explanation of Various Types of Charts Used in Business and of the Principles Governing the Correct Presentation of Facts by Graphical Methods. London

Thomas, K. C. 1933. Ability of Children to Interpret Graphs. In 32. Yearbook of the National Society for the Study of Education. pp. 492-494

Tobler, W. R. 1959. Automation in Cartography In Geographical Review 49, pp. 526-534. DOI: https://doi.org/10.2307/212211

Washburne, J. N. 1927. An Experimental Study of Various Graphic, Tabular and Textual Methods of Presenting Quantitative Material. In Journal of Educational Psyscology 18, pp. 361-376 és 475-476 DOI: $\underline{\text { https://doi.org/10.1037/h0074758 }}$

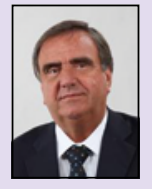

Dr.

Klinghammer István professzor emeritus

az MTA rendes tagja, ELTE Térképtudományi és Geoinformatikai Tanszék klinghammer@caesar.elte.hu 